Unholy Alliance.

\title{
The Connection between the East German Stasi and the Right-Wing Terrorist Odfried Hepp
}

Bernhard Blumenau

\section{Introduction}

On 18 February 1983, a young man, aged 23, suspected that the police were keeping his apartment under surveillance and took his rucksack, climbed onto an adjacent balcony to hide there until the police were gone. In the depth of night, he left the building and ran ceaselessly through the streets of West Berlin. Finally, to confuse his pursuers, he took several taxis, as well as the U-Bahn, to the Friedrichstraße checkpoint between West Berlin and the German Democratic Republic (GDR), where he arrived just before 6 am. Announcing himself to the East German border guards, he waited in a backroom until he was finally picked up by an officer of the East German State Security, the Stasi. ${ }^{1}$ This man, Odfried Hepp (aka 'Friedrich' in the Stasi files), was one of the most wanted right-wing terrorists ${ }^{2}$ in the Federal Republic of Germany (FRG) in the 1980s.

What sounds like an extract from a spy novel is only one of the highlights of a story that has all the basic ingredients of a thriller: murders and bank robberies, a young man driven by - however abhorrent - political and idealistic beliefs, Cold War politics, Palestinian 'freedom fighters', boot camps in the Middle East, spies, and fake identities. Yet this story, which is at the centre of this article, is not fiction - it is the very real account of the life of Odfried Hepp as well as a glimpse at radicalisation and political extremism as well as right-wing terrorism in West Germany, the dimensions of the GermanGerman Cold War struggle and the GDR's relationship with terrorism.

Scholarship on the links between the East German regime and leftist terrorist organisations such as the Red Army Faction (RAF) is becoming more readily available ${ }^{3}$ and shedding light on these

\footnotetext{
${ }^{1}$ AOPK 7896/91, Bd. 2, doc. 214-17, all archival documents cited here are from the Bundesbeauftragter für die Unterlagen des Staatsicherheitsdienstes der ehemaligen DDR (henceforth: BStU). All quotes are translations from German made by the author.

2 This article will not discuss the notion of 'terrorism' in detail, as a wealth of literature exists on this topic, see for instance Charles Tilly, 'Terror, Terrorism, Terrorists', Sociological Theory 22, no. 1 (March 2004): 5-13; Anthony Richards, Conceptualizing Terrorism, First edition (Oxford, United Kingdom ; New York, NY: Oxford University Press, 2015); Louise Richardson, What Terrorists Want: Understanding the Enemy, Containing the Threat (Random House Publishing Group, 2006), 20-22, 38-39; Bruce Hoffman, Inside Terrorism, Rev. and expanded ed (New York: Columbia University Press, 2006), 40-41; Richard English, Terrorism: How to Respond (Oxford: Oxford University Press, 2010), 4, 24. For the purpose of this study, 'terrorism' is defined as a tactic, employed by sub-state actors, that depends on using - or threating to use - violence for political purposes with the intention to create psychological effects beyond the immediate target.

${ }^{3}$ See for instance Christoph Daase, 'Die RAF Und Der Internationale Terrorismus. Zur Transnationalen Kooperation Klandestiner Organisationen', in Die RAF Und Der Linke Terrorismus, ed. Wolfgang Kraushaar, vol.
} 
important aspects of German-German as well as Cold War history, not to mention the history of terrorism. Several studies on the history of the Ministry for State Security (MfS) exist, such as Jens Gieseke's excellent overview Die Stasi, and literature on the extent of the Stasi's activities in the West - especially West Germany - offer better glimpses into the work of the MfS in 'enemy territory'. However, as historian and Stasi specialist Hubertus Knabe has argued, the links between the Stasi and right-wing terrorists in the West have still received insufficient attention and Anglophone scholarship is by and large still rather ignorant of the matter. ${ }^{4}$ Yet, this is a relationship worth studying, not least because, for ideological reasons, neo-Nazis were very unholy - yet as this article suggests, at least in some cases, highly courted - allies of a regime that claimed to be the forerunner of socialism as well as antifascism, and hypocritically accused the West German state of maintaining links with neofascism.

Based on documents from the Bundesbeauftragte für die Unterlagen des Staatsicherheitsdienstes der ehemaligen DDR (BStU) in Berlin this article will examine the contacts between East Germany and the West German neo-Nazi Odfried Hepp between 1981 and $1990 .{ }^{5}$ It will

2 (Hamburg: Hamburger Edition, 2006), 905-29; Tobias Wunschik, Die Hauptabteilung XXII: 'Terrorabwehr' (MfS-Handbuch) (Berlin: BStU, 1996), http://www.nbn-resolving.org/urn:nbn:de:0292-97839421301414; Bernhard Blumenau, The United Nations and Terrorism: Germany, Multilateralism, and Antiterrorism Efforts in the 1970s (Houndmills, Basingstoke, Hampshire ; New York, NY: Palgrave Macmillan, 2014), 29-32; Martin Jander, 'Differenzen Im Antiimperialistischen Kampf. Zu Den Verbindungen Des Ministeriums Für Staatssicherheit Mit Der RAF Und Dem Bundesdeutschen Linksterrorismus', in Die RAF Und Der Linke Terrorismus, ed. Wolfgang Kraushaar, vol. 1 (Hamburg: Hamburger Edition, 2006), 696-714. Investigative Journalist Regine Igel has also produced a book on the connections between the Stasi and terrorists; however the lack of empirical evidence for her argument has caused serious criticism, see Regine Igel, TerrorismusLügen: Wie die Stasi im Untergrund agierte, n.d.; Thomas Riegler, 'Rezension von: Regine Igel: TerrorismusLügen. Wie Die Stasi Im Untergrund Agierte, München: Herbig Verlag 2012', Sehepunkte 13, no. 11 (15 November 2013), http://www.sehepunkte.de /2013/11/24214.html.

${ }^{4}$ See Hubertus Knabe, Die Unterwanderte Republik: Stasi Im Westen (Berlin: Propyläen, 1999), 440. For general scholarship on the Stasi and its activities in the West see for instance Jens Gieseke, Die Stasi: 1945 - 1990, 4th ed. (München: Pantheon Verlag, 2011); Sven Felix Kellerhoff, Die Stasi und der Westen: Der Kurras-Komplex (Hamburg: HOFFMANN UND CAMPE VERLAG GmbH, 2010); Knabe, Die Unterwanderte Republik. Kristie Macrakis provided an excellent account of the technological side of Stasi activities, Seduced by Secrets: Inside the Stasi's Spy-Tech World, 1st Edition edition (Cambridge University Press, 2008). Popular culture also provides accurate accounts of life in 'Stasiland', see for instance Anna Funder, Stasiland: Stories from Behind the Berlin Wall (London: Granta, 2011); Florian Henckel von Donnersmarck, Das Leben der Anderen (Touchstone, 2005).Though the subject of contemporary debate, the extent to which the Stasi collaborated with and supported right-wing extremists and terrorists in West Germany is still unclear. See Wunschik, Die Hauptabteilung XXII: 'Terrorabwehr' (MfS-Handbuch), 35-36; Knabe, Die Unterwanderte Republik, 440. See also Samuel Salzborn, 'Die Stasi Und Der Westdeutsche Rechtsterrorismus. Drei Fallstudien', Deutschland Archiv, 19 April 2016, www.bpb.de/224934.

${ }^{5}$ The files on Hepp alone comprise scores of binders. The use of Stasi archives also begs a word of caution. Due to the secretive nature of these information, the efforts to destroy highly compromising material in 1989, and the lack of accessible information from West German agencies to corroborate the Stasi material leaves some of the findings of this article - especially with regards to actions taken or not - somewhat tentative. However, efforts were made to triangulate information from the Stasi files with other sources, such as newspaper articles that relied on interviews and files of the West German prosecutors. As the 30-year deadline on West German material lapses, more information might become available. Yet the intelligence agencies do not operate on the 30 -year policy and it might take significantly longer for information to be available, if at all. 
do so in order to determine why this cooperation materialised in the first place, what its dynamics were, and what benefits and risks it created for the Stasi. A short biography of Hepp, providing the raw data for the analysis in this article will also serve the purpose of introducing this highly interesting character to an Anglophone readership. It will be followed by an examination of the different stages of his relationship with the East German authorities while he was in respectively West Germany, East Germany, the Middle East, and France. In so doing, it will address primarily the perception and implications of the relationship from the point of view of Stasi officials as reflected in their reports something that has not been done yet. Yury Winterberg produced an extensive study based on interviews with Hepp and other documentation but it does not go in depth in the Stasi-Hepp relationship and does not cover it after Hepp's arrest in $1984 . .^{6}$ This article will therefore offer interesting insights into how the Stasi operated and into the extent to which the MfS - and by extension members of the highest echelons of the GDR's leadership - maintained close relations with and granted support to very unlikely bedfellows: right-wing terrorists. By probing the reasoning for these contacts, and discussing the risks that it posed for the MfS, this article will challenge common perceptions of the Stasi as an almighty and all-knowing entity in total control of their agents. The relationship between East Germany and Western terrorists is much more complex and the Stasi obviously found Hepp an asset and a liability at the same time. What becomes quite clear in this present case study is that there was only limited power the Stasi could yield to make Hepp abide by their orders - namely personal relationships - as they did not have major instruments of blackmailing or enforcement at their disposal. In fact, the Stasi and East German authorities at large depended on Hepp to not reveal his links with the GDR to Western authorities, who could have easily exploited these connections with terrorism to embarrass the GDR in front of global public opinion. This article, therefore intends to counter the simplistic views of terrorism as proxy tools of the Communist Bloc, advanced for instance by Claire Sterling, ${ }^{7}$ by scrutinizing one particular case study. By providing an

\footnotetext{
${ }^{6}$ Yury Winterberg - Der Rebell: Odfried Hepp: Neonazi, Terrorist, Aussteiger, 1st ed. (Bergisch Gladbach: Lübbe, 2004). The certain bias in this book - something the author alludes to himself on pp. 363-5 and which is probably inevitable for any biography - warrant a further, document-based study, which this article will provide. The same criticism applies to the documentary on Hepp, which is based on Winterberg's book: Jan Peter, Der Rebell (absolut Medien $\mathrm{GmbH}, 2006)$. Of particular interest for this article is not so much the personal biography and perspective of Hepp himself but rather the implications this arrangement had for the Stasi and how the organisation perceived of and dealt with their informant.

${ }^{7}$ The connections between the Eastern bloc and Western terrorists have generated debates that date back to the 1980s and the book by Claire Sterling about the Soviet control over most terrorist groups, see Claire Sterling, The Terror Network (New York: Henry Holt \& Co, 1981). As scholars such as Timothy Naftali have shown though, and this article will too, her hypothesis does not stand the empirical test and terrorist groups operated rather autonomously while drawing on occasional support from - rather than being led by - Eastern bloc countries, see e.g. Timothy Naftali, Blind Spot: The Secret History of American Counterterrorism (New York, NY: Basic Books, 2006); For an example of how other Eastern security agencies struggled with Western terrorists see also Daniela Richterova, 'The Anxious Host: Czechoslovakia and Carlos the Jackal 1978-1986', The International History Review 0, no. 0 (4 April 2017): 1-25, https://doi.org/10.1080/07075332.2017.1309560.
} 
archival study, this article also intends to contribute an empirical and historical enquiry to the field of Terrorism Studies, which, as is often lamented, is still in dire need of these evidence-based contributions. $^{8}$

\section{The Hidden Warriors of the Cold War? The Links Between the Stasi and Western Terrorism}

The connections between the East German regime and Western terrorists in general date back to the early 1970s. From their very beginnings, the two most prominent left-wing terrorist groups in West Germany, the Movement Second of June and the Red Army Faction (RAF), both sought contact with East Berlin. However, this relationship was not based on their alleged ideological affinity. In fact, West German left-wings terrorists eyed the GDR with a great deal of suspicion and the RAF leadership had much more adoration for Che Guevara, guerrilla warfare, and the so-called 'Cuban model' than orthodox notions of Socialism and Communism as promulgated by the GDR and Union of Socialist Soviet Republics (USSR). ${ }^{9}$ But due to the Cold War, the Eastern camp, and specifically the GDR, were potential allies. The major driving motive for this cooperation was the simple need for support, which East Berlin could readily provide. The Movement Second of June operated out of West Berlin - an island surrounded by the GDR - and having East German police and border guards turn a blind eye to terrorists using the GDR for transit was very welcome. The RAF had the same motivation. Having a nearby safe haven was immensely useful during extensive manhunts in the FRG - especially when it was very unlikely that any international arrest warrants would be acted upon in the GDR. Moreover, the RAF also hoped for direct support in the form of training or equipment. ${ }^{10}$

However, this relationship with Western terrorists also offered benefits to the Stasi. Following the logic of 'my enemy's enemy is my friend', there was a basis for cooperation with both terrorist groups. Allowing indirect support by providing transit was not a problem for the GDR regime. When it came to granting training and equipment though, things were different. The GDR - much like its allies - officially condemned terrorism and there could be no traceable public links whatsoever between

\footnotetext{
${ }^{8}$ See for instance the problem of the lack of primary sources as discussed in Marc Sageman, 'The Stagnation in Terrorism Research', Terrorism and Political Violence 26, no. 4 (1 September 2014): 565-80, https://doi.org/10.1080/09546553.2014.895649. For the lack of historical work see also Silke, Andrew, 'Contemporary Terrorism Studies: Issues in Research', in Critical Terrorism Studies: A New Research Agenda, ed. Jackson, Richard, Breen Smith, Marie, and Gunning, Jeroen (London, UK ; New York, NY: Routledge, 2009), 46; Isabelle Duyvesteyn, 'How New Is the New Terrorism?', Studies in Conflict \& Terrorism 27, no. 5 (September 2004): 439-54, https://doi.org/10.1080/10576100490483750; Duyvesteyn, Isabelle, 'The Role of History and Continuity in Terrorism Research', in Mapping Terrorism Research: State of the Art, Gaps and Future Direction, ed. Ranstorp, Magnus (Abingdon, Oxon: Routledge, 2007), 51-75.

${ }^{9}$ Tobias Wunschik, 'Baader-Meinhof International?', Aus Politik Und Zeitgeschichte, no. 40-41 (2007): 25.

${ }^{10}$ See for instance Karrin Hanshew, Terror and Democracy in West Germany, 1. paperback ed (New York, NY: Cambridge Univ. Press, 2014), 111-12. Not just from the GDR though. The RAF sent letters as far away as North Korea to ask for support, see Johannes Wörle, 'Erdung Durch Netzwerkstruktur? Revolutionäre Zellen in Deutschland', in Sozialrevolutionärer Terrorismus: Theorie, Ideologie, Fallbeispiele, Zukunftsszenarien, ed. Alexander Straßner (Wiesbaden: VS Verlag für Sozialwissenschaften, 2009), 266.
} 
these groups and the East German authorities. Consequently, there is no evidence of either training or arms being passed on to either terrorist group in the 1970s. ${ }^{11}$ In the early 1980s, however, the Stasi decided to take a risk, upon the orders of its Minister Erich Mielke, and allowed ten ex-terrorists to 'retire' in the GDR. They were given new identities and meticulously trained so that their true origins would not be revealed. This included resettling them if their real identities were discovered - and sending them as far away as the Soviet Union. ${ }^{12}$ But even low-key support could have serious repercussions: on the one hand, it was ideologically contradictory as the terrorists did not follow the Marxist-Leninist logic of how the Proletarian Revolution should come about (namely through the leading role of the Communist Party rather than other groups creating a momentum such as terrorists); on the other hand, in terms of international reputation, links with terrorism were dangerous should they ever be uncovered. ${ }^{13}$ The GDR certainly did not want to be seen as a state sponsor of terrorism. ${ }^{14}$ Moreover, the East Germans feared that terrorism could spill over into their territory. Liaising with the Movement Second of June or the RAF was therefore not so much about supporting them and keeping the social tensions in West Germany alive. But it was rather about gaining information and having a limited means of control regarding the activities of the terrorists, which could serve as an early warning system in case they ever turned against the GDR. ${ }^{15}$ This defensive notion of 'keeping your friends close, but your enemies even closer' was the major reason for the collaboration with Western terrorists. On the whole, and as the remainder of this article will show, terrorists were no proxies in the Cold War: the GDR did not see them as another brigade actively involved in the conflict. While the needle stings

\footnotetext{
${ }^{11}$ There is, however, speculation about a short period in the early 1980s when the Stasi might have trained members of the RAF in preparation for an attack on high-ranking NATO officers, and documents from the MfS seem to support this claim, see Wunschik, Die Hauptabteilung XXII: 'Terrorabwehr' (MfS-Handbuch), 44; Gieseke, Die Stasi, 247.

${ }^{12}$ The MfS held extensive documentation on operation 'Stern II' which included new identities for former West German terrorists starting a new life in East Germany. Susanne Albrecht for instance, alias 'Ingrid Jäger' or 'Ingrid Schubert', had to leave Köthen in Saxony after she was recognised as one of the wanted terrorists on West German tv. She first went to Berlin and was then sent to the Soviet Union together with her husband and child, see MfS-HAXXII 19897. Silke Maier-Witt, aka 'Angelika Gerlach' or later 'Anja Weber', also started a new life in East Germany, was recognised and had to relocate, see MfS-HAXXII 19611. Inge Viett alias 'Eva Maria Sommer' or 'Maria Berger' was also recognised as a West German terrorist and also relocated within the GDR, see Inge Viett, Nie war ich furchtloser: Autobiographie, 4th edition (Hamburg: Ed. Nautilus, 2007), 307-8. ${ }^{13}$ See for instance the US criticism of the GDR after the bombing of the West Berlin dance club 'La Belle' by Libyan terrorists in 1986. The US accused East Germany of allowing Libyan agents based in East Berlin to carry out the attack and sheltering them, see e.g. David C. Wills, The First War on Terrorism: Counter-Terrorism Policy During the Reagan Administration (Lanham, Md: Rowman \& Littlefield, 2004), 197.

${ }^{14}$ Although, of course, defining what exactly constituted 'terrorism' was a more ambiguous task for the eastern bloc, see for instance Bernhard Blumenau, 'The Other Battleground of the Cold War: The UN and the Struggle against International Terrorism in the 1970s', Journal of Cold War Studies 16, no. 1 (2014): 70-71.

${ }^{15}$ See several documents highlighting this notion in MfS-23120/91 SIVO.
} 
Western terrorist administered to the West German state were welcome, liaising with them was more a matter of self-protection for the Stasi. ${ }^{16}$

Consequently, for these reasons the Stasi maintained contacts with left-wing terror groups even though they were for ideological reasons not likely to strike the GDR. Yet, East German officials also interacted with ideologically opposed right-wing terrorists. As the following sections will reveal, the Stasi attempted to collaborate to gather reliable and intimate knowledge of their activities, irrespective of the individual past of the source providing it. This was realpolitik at its best.

\section{The Story of Odfried Hepp}

The biography of Hepp is interesting in itself also with a view to the question as to why people become terrorists - a topic unfortunately beyond the scope of this study. ${ }^{17}$ Odfried Hepp was born into a West German middle-class family with centre-right leanings in 1958 and early on, his father, who had left the GDR in the 1950s, encouraged him to join a right-wing youth organisation to learn discipline, comradeship, and other allegedly 'German' virtues. ${ }^{18} \mathrm{He}$ started in the right-wing Bund Heimattreuer Jugend and soon found a second home there. Hepp enjoyed the camaraderie of the organisation, the camping trips, and the history lessons that conveyed a much more positive picture of the Nazi past than in school, and he soon climbed the hierarchical ladder. In 1977, he joined the Viking Youth and also established his own group, the Wehrsportgruppe (WSG) Schlageter. ${ }^{19}$ Hepp claimed that he was driven to activism by the desire to liberate Germany from its alleged 'American occupation', to unite both Germanys, and to establish a pan-European alliance and security system. These goals run through Hepp's career as a leitmotif. In the earlier years, he advocated a neutral united Germany, overcoming divisions of 'left' and 'right' and living in peace and friendship with the USSR. But later on he started to lobby for a direct alliance with the USSR. ${ }^{20}$ The WSG Schlageter was supposed to create enough momentum within the broader population to implement these goals and was described by Hepp as '100\% National-socialist'. ${ }^{21}$ In September 1979, Hepp, was arrested and charged with founding a criminal - later changed to 'terrorist' - organisation by the West German police. He tried to escape but was apprehended, sentenced, and imprisoned, although his sentence was suspended in February 1980. The lack of support from his groups during his trial and imprisonment as well as the absence of

\footnotetext{
${ }^{16}$ For propaganda purposes, however, terrorism was readily abused in the Cold War, for instance at the United Nations, see e.g Blumenau, 'The Other Battleground of the Cold War'.

${ }^{17}$ There is an extensive body of literature on these topics, see for instance Martha Crenshaw, Explaining Terrorism, 1 edition (London ; New York: Routledge, 2010), esp. ch. 2; Tore Bjørgo, ed., Root Causes of Terrorism: Myths, Reality and Ways Forward, 1 edition (London; New York: Routledge, 2005); John Horgan, The Psychology of Terrorism, 2 edition (Abingdon, Oxon: Routledge, 2014), chap. 4.

${ }^{18}$ For his family background and childhood see Winterberg, Der Rebell, 12-46.

${ }^{19}$ Named after Albert Leo Schlageter, someone who had reached martyr status in Third Reich propaganda.

${ }^{20}$ See AOPK 7896/91 Bd. 1, docs .26-29, 31, 36-8, 41, 49-52.

${ }^{21}$ AOPK 7896/91, Bd. 19, doc. 15.
} 
any loyalty on the part of his former comrades who readily testified against him made Hepp turn his back on the organisation and start, what he himself called, his 'terrorist career'.22

Looking for like-minded radicals, in March 1980 Hepp met with Karl-Heinz Hoffmann, the most prominent West German militant neo-Nazi and founder of his own WSG. ${ }^{23}$ It quickly transpired that they had a mutual affinity for each other and Hepp agreed to travel with Hoffmann to his training camp, which had been set up together with Al Fatah, in Lebanon. He also convinced several of his friends to join and they committed a bank robbery in Hesse in July 1980 to fund the trip. ${ }^{24}$ In this context, it is interesting to note that in their initial stages, Hepp et al. did not differ much from leftwing terrorism in their methods and actions. The RAF members, following the advice of Carlos Marighella, ${ }^{25}$ also started their 'terrorist career' through bank robberies and Palestinian training camps in the Middle East. ${ }^{26}$

In Lebanon, Hepp and his comrades were based in the Bir Hassan camp, south of Beirut. Because of his commitment and discipline, Hepp quickly advanced internally and became Hoffmann's deputy. While the latter was away, Hepp was left in charge of the camp, but his tough regime quickly led to dissent with some of the other members of the group. When Hepp became disillusioned with the 'idiots and primitives' that belonged to his group, he and three others tried to escape in September 1980. However, on their way to the airport they were stopped by Al Fatah members, who feared that they were being betrayed and that information about their camp would be leaked to Western intelligence agencies. Therefore, Hepp and his comrades were taken back to the camp where they were imprisoned and tortured by other WSG members. He was released in December and reintegrated into the group. ${ }^{27}$ According to his account, Hepp fully re-dedicated himself to the group, thinking that with Hoffman back in charge things would once again be better. One of his co-escapees, Kai-Uwe Bergmann, was less fortunate and died as a result of the torture and mistreatment. Nevertheless, in the spring of 1981 Hepp realised that while he admired the Al Fatah members for their commitment to their cause, discipline, and alleged selflessness, he grew progressively unhappy with Hoffmann and his group. Consequently, in June 1981, he went to the West German embassy to reveal himself as a member of the Hoffmann group who was willing to testify against them. The next day, two officers

\footnotetext{
${ }^{22}$ AOPK 7896/91, Bd. 19, doc. 18. See also Winterberg, Der Rebell, 68-69.

${ }^{23}$ For more information on Hoffmann and his WSG, see for instance Rainer Fromm, Die «Wehrsportgruppe Hoffmann»: Darstellung, Analyse und Einordnung: Ein Beitrag zur Geschichte des deutschen und europäischen Rechtsextremismus (Frankfurt am Main ; New York: Peter Lang GmbH, Internationaler Verlag der Wissenschaften, 1998).

${ }^{24}$ Winterberg, Der Rebell, 69-75.

${ }^{25}$ Carlos Marighella, Minimanual of the Urban Guerrilla, 1969.

${ }^{26}$ Blumenau, The United Nations and Terrorism, 19.

${ }^{27}$ For an account of Hepp's time in the camp, see also Winterberg, Der Rebell, 75-139.
} 
from the West German Federal Police Office (Bundeskriminalamt, BKA) arrived in Beirut and took Hepp back to Germany. ${ }^{28}$

The experience of the training camp is crucial for understanding Hepp's further actions and his break with established right-wing activists. In his conversations with Hoffmann he unsuccessfully wanted to forge an alliance with other right-wing activists, such as Manfred Roeder to form a 'superopposition'. Yet, the egomaniacal characters of many leaders of the right-wing scene and refusal to cooperate with one another, coupled with the cruelty he had witnessed towards comrades disillusioned Hepp. ${ }^{29}$

Back in Germany, Hepp was sentenced to 16 months' imprisonment but was granted early release in December 1981. Soon after being set free he met Walter Kexel, with whom he would found a new group to fight the US and work towards their goal of a united Germany. Both Kexel and Hepp were inspired by the Palestinian struggle for liberation, rather than any right-wing groups or leaders in Germany, and gave themselves Arab aliases (Hepp, for instance, was 'Jussuf'). To support their own struggle for liberation (from alleged American imperialism), they committed bank robberies (which gave them 700,000 deutschmarks to spend on their activities) and then shifted towards bomb attacks. ${ }^{30}$ In the wake of the 'German Autumn' in 1977 and excessive left-wing terrorism in and against Germany, the FRG authorities were slow to realise that the attacks had not been committed by the RAF or the Revolutionary Cells but rather by right-wing terrorists - not unlike the authorities initial ignorance to the existence of a right-wing terrorist group, the Nationalsozialistischer Untergrund (NSU) in the early 2000s. ${ }^{31}$ At the same time, Hepp and Kexel distanced themselves from Hoffmann and other neo-Nazis by means of a manifesto, Abschied vom Hiterlismus (Goodbye to Hitlerism). In this text they condemned West Germany for being a pawn of the Western powers and rejoiced that 'there is a wall running across Germany which allows 17 million Germans to live healthily, while people in the West are morally and spiritually dying.' Instead of advocating a revival of Hitlerism, they proclaimed a war of liberation against 'Americanism' and the goal of overcoming domestic political divisions. They declared it their goal to have a neutral Germany living in peace and friendship with the USSR. ${ }^{32}$ This manifesto,

\footnotetext{
${ }^{28}$ Reports of his involvement with SWG Hoffmann and his trip to Lebanon can be found in AOPK 7896/91, Bd. 2, doc.268-76; AOPK 7896/91, Bd. 5, doc. 53; AOPK 7896/91, Bd. 7, doc. 338-340; AOPK 7896/91, Bd. 14, doc. 501-545. See also 'Neonazis: Thors Hammer Im Libanon', Der Spiegel, 19 January 1981; 'Neonazis in Nahost Betrogen Und Reingelegt', Der Spiegel, 29 June 1981.

${ }^{29}$ Winterberg, Der Rebell, 83, 89, 93-99, 102-3, 122-32.

${ }^{30}$ AOPK 7896/91, Bd. 1, doc. 36-8, 41, 49-52.

${ }^{31}$ AOPK 7896/91, Bd. 1, doc. 53. For more information on left-wing terrorism in Germany see for instance Hanshew, Terror and Democracy in West Germany; Blumenau, The United Nations and Terrorism, chap. 1. On the West German responses (and occasional ignorance) to right-wing terrorism, see for instance Peter Lehr, 'Still Blind in the Right Eye? A Comparison of German Responses to Political Violence from the Extreme Left and the Extreme Right', in Extreme Right Wing Political Violence and Terrorism, ed. Max Taylor, Mark Currie, and Donald Holbrook (London: Bloomsbury, 2013), 187-214.

${ }^{32}$ AOPK 7896/91, doc. 26-29.
} 
especially the positive attitude towards the USSR, not only served as an official expression of the rupture in Hepp's relationship with most right-wingers but also paved the way for a rapprochement with the GDR on ideological terms. Soon thereafter, in January 1982, he would, for the first time, make contact with the Stasi.

\section{The Hepp-Stasi Connection}

On 14 January 1982, Hepp met the MfS officers who would be in charge of him, Eberhard Böttcher and Hartmut Kießling for the first time. They would remain his contacts throughout the 1980s. Both were quite sceptical of a well-known neo-Nazi terrorist offering his services to the Stasi. In his conversation with them, Hepp pointed out that he never saw the GDR, or the Soviet Union for that matter, as an enemy but that his sole goal was to rid Germany of American occupation so as to allow both parts of the nation to unify and form a new alliance system in Europe that would also include the Soviets. More importantly for the Stasi, he also claimed that he had crucial information on future attacks on East German targets, including the MfS building itself, by a group centred around the right-wing extremist and stern enemy of the GDR, Werner Kley, as well as key intelligence on a planned right-wing operation in support of pro-Apartheid groups in South Africa. ${ }^{33}$ As it turned out, these plans were little more than fictions in Kley's head rather than serious endeavours, but the Stasi did not know this (nor did Hepp most likely). The Stasi had been anxiously looking for any signs that terrorism - of whatever political couleur - could spread from the West to the GDR and the possibility of attacks in East Germany made alarm bells go off. Therefore, Hepp looked like a valuable source and the MfS demanded more information on the matter. Further meetings took place and Hepp progressively became an important informant for the Stasi not just on Kley and his plans but also on the right-wing extremist scene in West Germany in general. Much like in the case of Stasi contacts with left-wing terrorism discussed above, the links with Hepp were primarily meant as a means to prevent possible dangers to the GDR but also to receive insider information on extremist movements. Ideological pragmatism characterised the Stasi's approach and little attention was paid to Hepp's neo-Nazi convictions.

Yet, the MfS agents remained sceptical regarding any possible ulterior motives Hepp could have for approaching the MfS. While the leadership at the Stasi agreed that their officers should continue to meet with him, special precautions were also taken to avoid any evidence of these encounters that could compromise the MfS publicly. Böttcher feared that Hepp could be a West German 'agent provocateur' of the Bundesnachrichtendienst (BND) who could be trying to publicly embarrass the East German regime by showing that they maintained contacts with right-wing

\footnotetext{
${ }^{33}$ Winterberg, Der Rebell, 218-19. AOPK 7896/91, Bd. 1, doc. 21. Kley had intimate contacts with apartheid supporters in Namibia who asked him for support and manpower to commit attacks against SWAPO, see AOPK 7896/91, doc. 23.
} 
extremists. And indeed, had the Stasi connection with Hepp been revealed it would have been a major humiliation for GDR officials, especially so as the East German government never missed an opportunity to openly and vocally condemn the alleged legacy of fascism and Nazism in the FRG. ${ }^{34}$ Nonetheless, West German agents were not the only concern of the Stasi: MfS officers were also worried that Hepp could be working for the PLO because of his trip to Lebanon in 1980/81 and his open admiration for the Palestinian cause. ${ }^{35}$ These risks notwithstanding, the Stasi was tempted by the potential benefits of having a source in the rightist-extremist scene in the FRG and the enticing wealth of information that the Stasi could obtain from him, so the cooperation continued. At the same time though, the MfS started a surveillance operation (Operative Personenkontrolle, OPK) - 'Adler II' - to verify the information that Hepp provided by comparing it to the intelligence delivered by other GDR agencies and informants in order to establish whether Hepp, or 'Friedrich' as he was now code-named, was indeed reliable and trustworthy. ${ }^{36}$

In terms of ideology, some common ground was emerging as well. Hepp underscored the ideas expressed in his political manifesto. He stressed that the only solution to the 'German Question' lay in a united Germany closely allied with the USSR in political, military, and economic matters and that he was committed to the struggle against fascism and the US. ${ }^{37}$ This went beyond Hepp's earlier speeches as he had never before called for a unified Germany in the Soviet zone of influence, only a neutral Germany. Whether this new statement aligned with his actual beliefs is difficult to establish - his future behaviour suggests this was indeed the case - but it was also certainly an attempt to endear himself to the East German authorities by making his overtures to the Stasi more ideologically sound. The meetings continued and Böttcher's and Kießling's stance on Hepp would, over the years, move from scepticism to trust and - eventually - even friendship. In particular, Böttcher seemed to have a certain - very un-East German - admiration for the 'German loyalty' and 'Germanic' attitude he saw in Hepp and their relationship resembled one of a father and son..$^{38}$ Yet, this also shows the large extent to which personal relationships between Stasi officers and their sources mattered and affected decisions taken in the MfS. This will be a recurring feature of Hepp's further dealings with the Stasi.

Over the course of 1982, the cooperation seemed to pay off for the Stasi. Hepp, for instance, provided information that were used to identify some staff of the BKA, and other intelligence agencies

\footnotetext{
${ }^{34}$ The Stasi was actively involved in highlighting the alleged involvement of West German politicians in Nazi crimes, see for instance Gieseke, Die Stasi, 223-24. Naturally, the GDR saw itself, by default, as staunchly antifascist, see the chapters in Uwe Backes, Ralf Thomas Baus, and Herfried Münkler, Der Antifaschismus als Staatsdoktrin der DDR, Eine Veröffentlichung der Konrad-Adenauer-Stiftung e.V (Sankt Augustin: KonradAdenauer-Stiftung, 2009), http://www.kas.de/wf/doc/kas_15070-544-1-30.pdf?100617131827.

${ }^{35}$ AOPK 7896/91, Bd. 1, doc. 7-8.

${ }^{36}$ AOPK 7896/91, Bd. 1, doc. 7-8, 31.

37 AOPK 7896/91, Bd. 1, doc. 31

38 'Du Bist Jetzt Einer von Uns', Der Spiegel, 18 November 1991, 137. Winterberg, Der Rebell, 251. Böttcher repeated his positive impression of Hepp in the 2006 documentary by Peter, Der Rebell.
} 
and their vehicles. ${ }^{39}$ This information was very useful to prevent the detection of East German spies in the West. ${ }^{40}$ The most useful intelligence that Hepp provided, however, were on possible right-wing attacks against the GDR and he was told to actively prevent any such attacks. ${ }^{41}$ At the same time though, Hepp's relationship with the Stasi was becoming a liability as he was put under progressively closer surveillance by the West German police and intelligence agencies. Being anxiously aware of the perils this posed for him, but especially his Stasi connection, his MfS officers urged Hepp to refrain from drawing attention to himself. ${ }^{42}$

Yet, Hepp did not follow the Stasi's advice - read: order - to keep a low profile. Without telling his MfS contacts, Kexel and him planned several bomb attacks against US army installations in the FRG. Three assaults were committed by Kexel between September and December 1982: an attack against US army housing near Frankfurt, an attempt on the car of a US army officer near Gießen, and another bomb placed under a US army car on 14 November 1982. Hepp himself was then involved in a concerted attack on US army cars in Darmstadt, Frankfurt, and Butzbach on 17 December 1982. These assaults resulted in several people being severely injured. ${ }^{43}$ The intention behind their attacks was to deliberately target the lower ranks of US soldiers and to raise the costs for US troops in Germany, financially and psychologically, so that pressure would rise to withdraw them. ${ }^{44}$

Rather than playing the role of a passive underground informant for the MfS, Hepp continued his offensive strategy against the US, which together with the fact that he never accepted any money from the Stasi except for the reimbursement of his travel expenses, might indicate that he indeed sought the contact not for personal benefit but because he genuinely believed that he and the MfS shared some common ground. This assessment is also supported by the fact that while RAF terrorists would approach the GDR for transit, training, and equipment, but certainly not for ideological discussions, it was different in the case of Hepp: he willingly argued with Böttcher and Kießling about politics and ideology. ${ }^{45}$ Operationally, the GDR had little to offer him - his coffers having been filled by recent bank robberies - and the dynamics of the relationship were not greatly uneven: Hepp approached the Stasi not from the position of beggar but on a roughly equal footing; he did not need them. ${ }^{46}$

\footnotetext{
${ }^{39}$ Winterberg, Der Rebell, 230.

40 Of which there were many, see Gieseke, Die Stasi, 220-23; Knabe, Die Unterwanderte Republik; Kellerhoff, Die Stasi und der Westen, 310-11.

${ }^{41}$ AOPK 7896/91, Bd. 1, doc. 83.

${ }^{42}$ AOPK 7896/91, Bd. 1, doc. 32-33, 46, 83.

${ }^{43}$ AOPK 7896/91, Bd. 1, doc. 36-8, 41, 49-52.

44 Winterberg, Der Rebell, 196.

${ }^{45}$ On the RAF-Stasi contacts, see for instance Wunschik, Die Hauptabteilung XXII: 'Terrorabwehr' (MfSHandbuch), 43-46; 'Denen Trauen Wir Jetzt Alles Zu' , Der Spiegel, 1 April 1991.

${ }^{46}$ Another reason might be that Hepp enjoyed the feeling of power he was experiencing as a Stasi spy, see Winterberg, Der Rebell, 224-25.
} 
These dynamics changed, however, when the West German police identified him as one of the instigators of the bomb attacks on the US military, which led to an attempt to arrest him on 18 February 1983. Hepp managed to flee in the thriller-like manner described at the beginning of this article. Now, Hepp had to ask the MfS for help. He hoped to be sheltered in East Germany, expressed interest in receiving training, and wanted to eventually seek refuge in a GDR-friendly Arab country. ${ }^{47}$ It was at this stage that he provided full disclosure on his complicity in the December 1982 bomb attacks. ${ }^{48}$ This lack of knowledge of Hepp's involvement in these attacks also showed the limitations of Stasi OPKs and the delicateness of the MfS's relationship with one of the most wanted criminals in West Germany.

Now, and in exchange for asylum, Hepp put himself fully at the mercy of the GDR. As an internal Stasi report highlighted: 'Hepp is willing, without conditions, to agree to any proposals by the MfS for his future life. He expressed the hope, however, that he be protected from arrests by hostile police forces on the grounds of the international arrest warrant against him. ${ }^{49}$ The relationship between Hepp and the Stasi had transformed into one that the Ministry was more used to; one in which the Stasi had the greater leverage. Yet, Hepp's escape into the GDR also meant that he would be in constant and immediate contact with his case officers and by early May 1983, they were finally convinced that he was not working for the BND and that he was trustworthy. ${ }^{50}$ Böttcher and Kießling described him in almost loving terms: 'he is sociable and adaptable, courageous, deft, and has good general knowledge. He is in an excellent physical condition, able to work under pressure, and aesthetically pleasing. ${ }^{51}$ Certainly both Stasi officers were quite taken with Hepp.

Hepp and the Stasi had reached the climax of their mutual relationship. By May 1983, he had provided information on almost 250 members of the neo-Nazi scene in West Germany and their GDR contacts. He had also identified BKA staff and provided accounts of five possible informants of the West German police in the neo-Nazi scene. ${ }^{52}$ Hepp had become a useful resource for the MfS but he also remained a liability as long as he stayed on GDR territory. Consequently, Böttcher and Kießling supported Hepp's request to be sent to an Arab country in order to start a new, low-profile life there. The Syrian Arab Republic transpired as a possible destination as Hepp believed he could easily live there and integrate himself; and the MfS leadership was sympathetic to the plan, also because sheltering him in the GDR was getting expensive. ${ }^{53}$ Moreover, with some wanted left-wing terrorists living undercover in the GDR, East Germany was already exposed to possible high public relations costs

\footnotetext{
47 AOPK 7896/91, Bd. 1, doc. 33.

48 AOPK 7896/91, Bd. 1, doc. 147

${ }^{49}$ AOPK 7896/91, Bd. 1, doc. 86.

${ }^{50}$ Winterberg, Der Rebell, 245-52.

${ }^{51}$ AOPK 7896/91, Bd. 1, doc. 94.

52 AOPK 7896/91, Bd. 1, doc. 32-33, 95-96.

${ }^{53}$ Winterberg, Der Rebell, 253. AOPK 7896/91, Bd. 1, doc.119.
} 
if this was ever revealed. Providing shelter to a wanted right-wing terrorist could have had even more tremendous negative effects for the GDR's credibility and international prestige and therefore the appeal of the plan to send Hepp away is evident. Yet this scheme also bore risks for the MfS as they would have only little control over Hepp once he was in the Middle East and he had already proven that he was not always willing to follow Stasi orders. Moreover, there was no guarantee that he would not reveal his Stasi connection to Arab or Western intelligence agencies if he were arrested. However, the fact that the Stasi continued with the Syria plan, despite the obvious risks, demonstrates the level of trust that had been established between the MfS officers and Hepp and to what extent personal relationships could not only work in the favour of the MfS - to exploit sources - but also to the advantage of the informants themselves. Had Hepp not been able to win his case officers over on a personal level, their support for this plan would have certainly been meagre and the likelihood of it ever being implemented low.

The details of Hepp's move to Syria and his cover stories soon took shape: he would pretend to be a West German citizen (using a fake passport provided by the Stasi), who was visiting Syria with the intention of learning Arabic. But to avoid that Hepp's true identity was discovered - and thus his connections to the Stasi - he was under explicit instructions to avoid any contact with the PLO and his Stasi officers warned him that failure to do so would have 'dangerous consequences'. ${ }^{54}$ Should he happen to meet one of his former al Fatah contacts, he was instructed to say that he had to leave Germany because of a pending arrest. As a precaution, the Stasi also refrained from informing their Palestinian contacts about Hepp's trip to Syria so as to prevent any possible ties between them and Hepp from being revealed..$^{55}$ In Syria, Hepp was supposed to find a good place to live, befriend locals, find a job, learn the language and culture, avoid any contact with Western people and Hepp's family, and - importantly - find a girlfriend and settle down. ${ }^{56}$ All of this would allow him to build a new life, and most crucially, to keep a low profile and not raise any suspicions. The potentially serious consequences and risky character of this operation can also be seen from the fact that during the whole process, the head of the MfS, Minister Erich Mielke was kept apprised and personally approved of Hepp's relocation to the Middle East. ${ }^{57}$

As his departure to Syria approached, the Stasi trained Hepp with the goal of 'creating a realistic impression of the GDR and who's the real friend and enemy' - they indoctrinated him with the intention of tying him more closely to the MfS, and attempting to move him away from his rightist

\footnotetext{
54 Ibid.

${ }^{55}$ AOPK 7896/91, Bd. 1, doc. 98-9; AOPK 7896/91, Bd. 15, doc. 118. Originally the Stasi had still planned to allow Hepp to use his PLO contacts to make it easier to settle down in Syria but soon they changed their mind because of the risks, see AOPK 7896/91, Bd. 1, doc. 98-9.

${ }^{56}$ AOPK 7896/91, Bd. 1, doc. 113-4

${ }^{57}$ AOPK 7896/91, Bd. 1, doc. 43, ${ }^{57}$ AOPK 7896/91, Bd. 15, doc. 120.
} 
extremist, neo-Nazi ideology. ${ }^{58}$ These efforts seems contradictory with the goal of getting rid of him but then again, this tactic made sense. Bringing him in line with the GDR ideologically and creating a tighter bond with his case officers would allow the Stasi to cement his loyalty to them in order to ensure that he would obey the Stasi orders during his trip to Syria. It provided a means of controlling and influencing Hepp once he was outside of the Stasi's sphere of influence. Moreover, the MfS had plans to potentially use him as an informant on Syria after a couple of years, once he had settled in properly, and thus creating a close relationship and ideological affinities were necessary. ${ }^{59}$ To convince him of the many wonders of Socialism he was also taken on several trips around the GDR. ${ }^{60}$

This programme seemed to pay off - at least to some extent. In the summer of 1983, the Stasi grew progressively more satisfied with Hepp. Böttcher and Kießling confirmed that he could be of use for future operations that required 'all-out commitment' and they were convinced that he would under no circumstances reveal his GDR connection - which, currently available information seems to suggests, he never did as long as the GDR existed.$^{61} \mathrm{He}$ was judged psychologically and physically fit to do the MfS' bidding and having undergone intensive political education - together with the excursions in the GDR - allegedly developed a strong ideological connection and affinity for the GDR. ${ }^{62}$ While, frustratingly for the Stasi, he did not entirely give up his neo-Nazi beliefs, his two case officers attempted to convince him that 'Marxism-Leninism could give clear answers to his questions and problems. ${ }^{163}$ As far as terrorism as a tactic was concerned, however, Hepp continued to believe that 'terror was an acceptable method with a signalling effect' even though Böttcher and Kießling told him that this was absolutely wrong. According to Marxist-Leninist doctrine, so they argued, revolution would only come about through a mass movement led by the Communist Party, not through individual terror. ${ }^{64}$ But no consensus was reached on this aspect and this should have been reason for concern at the MfS. With Hepp leaving their immediate zone of influence and the possible embarrassment he could have been to the GDR it seems risky to let him leave without swearing off from terrorism. A key pillar of his new life would be to keep a low profile but his continuing flirtation with the rightfulness of terrorism could easily turn the Hepp affair into a powder keg and compromise his alibi and Stasi links.

\footnotetext{
${ }^{58}$ AOPK 7896/91, Bd. 1, doc. 95-6.

${ }^{59}$ Winterberg, Der Rebell, 251-52. AOPK 7896/91, Bd. 1, doc. 116-7

${ }^{60}$ AOPK 7896/91, Bd. 13 doc 284.

${ }^{61}$ At least the current documentary evidence seems to suggest that. However, currently unavailable access to West German intelligence files will be crucial to prove or challenge this assumption.

62 Winterberg, Der Rebell, 251.

63 AOPK 7896/91, Bd. 1, doc. 116-7

${ }^{64}$ Later on in the process, they conceded in their conversations with Hepp, after the revolution succeeded, 'red terror' might be needed to counter 'white terror' as in the case of the USSR after the October Revolution. Yet they made it very clear to him that terror as it was committed by groups in the West would only help the enemy as it justified more repressive actions on the part of Western governments, including the FRG, see AOPK 7896/91, Bd. 5, doc. 264, 341-2
} 
It seems, again, that the personal impression his case officers had of him gave them the confidence to trust that this plan would work.

As for his future in Syria, it was decided that Hepp should move to Tartus and under no circumstances should he come back to the GDR on his own initiative.${ }^{65}$ The Stasi furnished Hepp with the passport of a West German, Dieter Kersten, and he received a suitcase full of Western clothes and cosmetics, and 10,000 deutschmarks in cash. ${ }^{66}$ Any hints as to his stay in East Germany were eradicated - for example, the dental fillings that he had received during his refuge in the GDR had to be taken out and were replaced with Western sealings. ${ }^{67}$ Even when faced with other Eastern security agencies not to mention the PLO - he was instructed to deny his GDR links. ${ }^{68}$ This interesting instruction demonstrates that the cooperation, full disclosure, and solidarity among the Socialist countries in the field of intelligence cooperation only went so far. The GDR did not even want its Eastern 'brothers' to know about their link with a neo-Nazi.

It was further agreed that Hepp would meet his case agents on 1 November 1983 at the Hotel Royal in Budapest to see how he was faring, discuss any problems, and to set a date and place for the follow-up meeting. ${ }^{69}$ The point of scheduling these meetings in advance was to avoid Hepp having to get in touch with the Stasi and thus limit the traceable contacts to a bare minimum. Then again, the MfS was also eager to keep some contact with Hepp. One reason was certainly to ensure that he was sticking by their arrangement and not at risk of disclosing his Stasi ties. Yet they also wanted to keep him as a potential spy in the Middle East further down the road, should this become necessary. One factor in MfS calculations was certainly that the Middle East was once again moving into the focus of global attention after the Iranian Revolution and the rise of anti-Western political Islam that manifested itself in the Beirut barrack bombings on 23 October 1983, just as Hepp was settling in in Syria. ${ }^{70}$ Unlike the RAF terrorists resettled in the GDR that had no more use for the Stasi in terms of intelligence or operations, Hepp remained a potential future asset.

\section{Hepp in the Middle East: Syria and Tunis}

On 22 July 1983, the day of Hepp's departure for Syria had finally arrived. He received a 'grand' goodbye with a boat trip and a lunch with Böttcher and Kießling, who even hugged him when they bid each other their final farewells. ${ }^{71}$ Hepp left from the East Berlin airport of Schönefeld on an Interflug

\footnotetext{
${ }^{65}$ AOPK 7896/91, Bd. 1, doc. 118, 175

${ }^{66}$ AOPK 7896/91, Bd. 1, doc. 117, 131; AOPK 7896/91, Bd. 5, doc. 202-4.

${ }^{67}$ AOPK 7896/91, Bd. 1, doc. 177.

${ }^{68}$ AOPK 7896/91, Bd. 1, doc. 119

${ }^{69}$ AOPK 7896/91, Bd. 1, doc. 133.

${ }^{70}$ AOPK 7896/91, Bd. 5, doc. 262. On the bombings see for instance Matthew Levitt, Hezbollah: The Global Footprint of Lebanon's Party of God (Georgetown University Press, 2013), chap. 2.

${ }^{71}$ AOPK 7896/91, Bd. 5, doc. 291-2
} 
flight to Damascus and settled down in Aleppo. ${ }^{72}$ According to his own reports, he started befriending several local students and taking Arabic classes. The biggest problem for Hepp was that he could not get a long-term tourist visa, so he had to renew his visa every couple of weeks. ${ }^{73}$ Not only was this an inconvenience but it also meant that his status was constantly checked and he thus remained in the spotlight of the authorities rather than disappearing off the radar screen as had been the plan. This, combined with the poor hygienic conditions and his inability to integrate himself properly and to find a job, led him to develop plans to move to the more 'European' Tunisia instead. He put these plans to Böttcher and Kießling during their first meeting in Budapest in November 1983 and they reluctantly agreed to his relocation. ${ }^{74}$ Overall though, the two Stasi agents were satisfied with his conduct thus far and his low-profile behaviour in Syria. ${ }^{75}$ Apart from the situational problems Hepp faced in Syria and his relocation to Tunisia, no major difficulties appeared to exist.

Having secured the Stasi's consent, on 31 December 1983, Hepp left Syria and moved to Tunisia, where long-term visas were easily available for West German citizens. During his attempts to settle in and connect with locals, Hepp met Mohammed Ghadban, ${ }^{76}$ a member of the PLO and the Palestinian Liberation Front (PLF) and became friends with him. This clearly violated Hepp's deal with the Stasi that he should avoid any contact with Palestinians and their organisations. Not only did Hepp meet with Ghadban on a regular basis but the latter also introduced him to the PLF and its infamous leader Abu Abbas. Abbas, alias Muhammad Zaidan, ${ }^{77}$ hosted Hepp in his house and during several long conversations, Hepp revealed his true identity to him but, according to his own reports, kept silent about his Stasi connection. Hepp became progressively more involved with the PLF and it soon transpired that there were dangerous strings attached to Abbas' hospitality. In exchange for free lodging and protection from the police, Hepp was to get in touch with his right-wing contacts in the FRG and persuade them to join PLF operations in Europe. Being notoriously short on cash - and the

\footnotetext{
${ }^{72}$ AOPK 7896/91, Bd. 1, doc.131, 149.

${ }^{73}$ AOPK 7896/91, Bd. 8, doc. 110-118.

${ }^{74}$ AOPK 7896/91, Bd. 1, doc.149; AOPK 7896/91, Bd. 8, doc. 119. See also Winterberg, Der Rebell, 261-63.

${ }^{75}$ AOPK 7896/91, Bd. 8, doc. 121.

76 According to the Stasi files, Ghadban was born in 1948 and of Lebanese origins. He had two children and had been involved in attacks against American and Syrian targets accusing the Syrian government of being an enemy to the 'progressive forces in Lebanon and a serving imperialism' (doc. 2). He was described as a 'womanizer' and a look-alike of Greek (sic!) singer Julio Iglesias, see the extensive file on Ghadban in AOPK 7896/91, Bd. 12. For more information on him see also Winterberg, Der Rebell, 269. The fact that Iglesias was not Greek but Spanish shows the Stasi's lack of understanding of Western pop culture or the sometimes very sloppy background research they did.

${ }^{77}$ He masterminded the Achille Lauro hijacking in 1985 and was arrested by US forces in Iraq in 2003, where he had been in hiding and sheltered by Saddam Hussein and where he also died the following year, see 'Amerikaner Verhaften Terroristenchef Abu Abbas', Frankfurter Allgemeine Zeitung, 16 April 2003, http://www.faz.net/-gpf-42ch; David Johnston, 'Leader of '85 Achille Lauro Attack Dies at Prison in Iraq', The New York Times, 10 March 2004, http://www.nytimes.com/2004/03/10/world/leader-of-85-achille-lauroattack-dies-at-prison-in-iraq.html.
} 
attacks in Europe would be costly - Abbas also wanted Hepp to bring the money from his bank robberies from Germany to Tunisia. Hepp protested that this would put him in an extremely risky situation as he could easily be arrested in West Germany but Abbas dismissed these concerns and insisted it was pay-back time for the hospitality Hepp had enjoyed. ${ }^{78}$ Against this backdrop, Hepp got in touch with Böttcher and Kießling outside of their regular meetings - in yet another violation of his agreement with the Stasi - and met them a month earlier than scheduled in East Berlin, of all places. ${ }^{79}$ Certainly, it was clear by now that the whole Hepp operation did not play out the way that the MfS had planned it. Hepp did not keep a low profile at all and his becoming progressively more entrenched in the PLF could also have repercussions for the Stasi. Not only was he beginning to show signs of panic but he also disobeyed all the safety mechanisms put in place and thereby risked exposing his Stasi connection.

One would assume that at this stage, the MfS would have cut its losses and discontinued their relationship with Hepp. Forcing him to move again, or disavowing him now would be less risky than letting him continue with his PLF work and running the risk of him being arrested while committing an attack. Had his Stasi link then been disclosed, it would have supported conspiracy theories, such as Claire Sterling's Terror Network, that were circulating at the time.

However, one could also argue that it was already too late to discontinue cooperation with Hepp. The only likely evidence for his relationship with the Stasi was his own statement anyway, unless Western intelligence agencies could produce any other corroborating material. Continuing the relation was certainly a risk but Hepp also remained a valuable source of intelligence for the Stasi regarding the PLF: in his assessment, the PLF had little to do with the PLO and more with Abbas' own power trips and aspirations: 'spontaneity and promoting his personal interests and prestige are typical of their approach. ${ }^{80}$ Hepp informed the Stasi of three planned attacks in Europe and of Ghadban's intention to build up commandos in Madrid, Paris, Rome, Bern, and Geneva. ${ }^{81}$ All of this was in blatant contradiction to Abu Abbas' public statements that the PLF was not planning any attacks in Europe; and it was certainly useful intelligence for the Stasi. ${ }^{82}$

Consequently, Kießling and Böttcher did not stop their cooperation with Hepp but instead urged him not to participate in the planned PFL attacks as they were deemed 'useless' and counterproductive for Palestinian interests. Above all, though, they were highly risky, not least for

\footnotetext{
${ }^{78}$ See Winterberg, Der Rebell, 273-76. AOPK 7896/91, Bd. 8, doc. 203-205.

${ }^{79}$ Hepp's trip to Berlin also led to another risky situation as he did not reveal his East German connection to his PLF comrades and did not inform them of his trip there. So Hepp was seriously frightened to see several PLO and PLF members on his Interflug plane to Schönefeld, but no one seemed to recognise Hepp, see ibid. 
Hepp himself and - by extension, the Stasi. He was instructed to impress on Abbas that it was imperative for his own safety to keep a low profile. Realising, however, the extreme pressure that Hepp was under from the PLF, Böttcher and Kießling also granted him some leeway for ad hoc decisions but within clear limitations. He was explicitly told not to travel back to Germany. Aside from this, the Stasi now started actively using him as an informant. He was told to identify any PFL threats to the GDR, but also - interestingly - to Syria, or the PLO; and if need be - as far as dangers for the GDR were concerned - he was ordered to actively counter them. ${ }^{83} \mathrm{Hepp}$ had, de facto, turned into an active Stasi agent.

Upon his return to Tunis, the PLF rewarded Hepp's work by making him an official member of their organisation, and gave him the alias 'Omar Saad Tariq'. Nevertheless, this came with a price tag, and Abbas continued to pressure Hepp to contribute directly to the PLF efforts in Europe and to help Ghadban. As the PLF also threatened to withdraw protection and housing from Hepp, he finally agreed to become actively involved, despite Stasi instructions to do the opposite. Therefore, in August 1984, Hepp travelled to West Germany via Madrid and Metz. The task assigned to him by Abbas was to approach some of his former neo-Nazi comrades to see if they were willing to cooperate with the PLF. He also used the opportunity to pick up some of his belongings, but failed to locate one of the money depots Kexel had dug. ${ }^{84}$

When he met with Kießling and Böttcher's superior Horst Franz later that year, they reprimanded him for having once again disobeyed their orders. In their reports, Franz and Kießling criticised Hepp's behaviour but also, curiously, defended his actions by emphasising the particular situation and the immense pressure he had been put under by the PLF. The fact that Hepp provided them with a detailed list of more than 1000 members of the neo Nazi scene in Germany - something he brought back from his trip to West Germany - placated Franz. ${ }^{85}$ Once again, the question came up as to how to proceed with Hepp who was turning into a loose cannon. Yet once again, the MfS decided to continue the modus operandi. It was decided that it would be better to maintain the links, albeit at longer intervals, to have some kind of control over his actions and whereabouts, as well as to extract intelligence, and thus be able to estimate possible future risks for the Stasi. ${ }^{86}$ The likelihood of Hepp's stay in the GDR or his ties to the Stasi being discovered by the West Germans were judged to be very low, as the BKA allegedly thought that he was in the Netherlands.$^{87}$ This assessment notwithstanding, he was certainly a high-profile criminal and even Chancellor Helmut Kohl had made it clear on several

\footnotetext{
${ }^{83}$ AOPK 7896/91, Bd. 8, doc. 205-7

${ }^{84}$ AOPK 7896/91, Bd. 13, doc. 285-7. See also Winterberg, Der Rebell, 277, 281, 291-93.

${ }^{85}$ Winterberg, 292-93.

${ }^{86}$ AOPK 7896/91, Bd. 8, doc. 561-3.

${ }^{87}$ AOPK 7896/91, Bd. 8, doc. 296-7.
} 
occasions that his government would do everything possible to apprehend him. ${ }^{88}$ Therefore, the possibility that he might be discovered and arrested remained and he continued to be a risk for the Stasi even though this was downplayed by the MfS officers.

At the same time, it is worth noting that Hepp wanted to meet with Böttcher and Kießling. For him too, the meetings posed a serious danger of being discovered and it was unclear how the PLF would react if they learnt that he was in league with the East. Moreover, having so blatantly disregarded the Stasi's instructions for his actions in Tunisia there was also a risk that the East Germans themselves could act in a way that would prevent their connections with Hepp from being disclosed: detain him and hide him in some prison in East Germany, or worse. Yet Hepp sustained contact with them, which shows that he either believed that there was still support he could receive from the GDR or, that in fact, he did have a certain affinity for the MfS and the GDR, and the personal relationship developed between him and the two Stasi men mattered to him. His sense of 'German loyalty', which Böttcher had so admired, might explain his behaviour.

Yet the continuing risk, which Hepp posed for the Stasi, led to internal MfS actions. Other departments within the MfS started monitoring Hepp's case more closely and criticised the handling of the situation. In an internal report, earlier evaluations of Hepp's personality and reliability were questioned. In particular, using Kießling's and Böttcher's assessment of Hepp's alleged self-discipline, obedience, and sense of responsibility as the justification for continuing contact with Hepp was harshly criticised. It was stated that their judgement alone would be a poor basis for such a risky operation. The report suggested that Hepp be forced to cut his ties with the PLF and relocate to a country where there was no PLO presence. If he refused to abide, his case officers should pretend that the West Germans had learnt about his stay in Tunisia, and that it was vital that he left as soon as possible so as not to be arrested. If this failed, all contact with Hepp would be suspended immediately. ${ }^{89}$ At this stage, some time after Hepp started actively engaging in PFL operation, the Stasi was finally preparing to put an end to this relationship. However, before any decision on further steps could be made, the worstcase scenario occurred: Hepp was arrested in France.

\section{The Arrest and its Aftermath}

In April 1985, Abbas sent Hepp to Paris to help Ghadban organise operations for the PLF in Europe. Upon his arrival on 9 April, Hepp was apprehended by the French intelligence agency which was tipped off by Ghadban who was already in custody ${ }^{90}$

\footnotetext{
${ }^{88}$ See the newspaper clips in AOPK 7896/91, Bd. 1, doc. 92.

${ }^{89}$ AOPK 7896/91, Bd. 8, doc. 564-8.

${ }^{90}$ AOPK 7896/91, Bd. 1, doc. 135, 140, 143.
} 
As a consequence of his arrest, Hepp was obviously not able to meet Böttcher and Kießling for their next meeting in Budapest, which was scheduled later in the month. ${ }^{91}$ Both officers were, however, quite confident that he would not betray them by revealing his connections with the MfS to Western intelligence services or uncovering the identities of the Stasi officers he had met. The MfS immediately started assessing the situation and several ad hoc reports pointed out that neither the French nor the West Germans would be able to discover any links whatsoever that would tie Hepp to the GDR as all traces of his trip to East Germany had been carefully erased.$^{92}$ Surprisingly though, rather than being upset by the arrest and Hepp's refusal to abide by their instructions, in internal reports Böttcher and Kießling defended his decision to go to Europe, once again. They underscored that his trip to Paris was against their orders but necessary as the PLF would only recognise him and protect him if he contributed to their actions. What they said in essence was that Hepp could only reduce the risk for his relationship with the Stasi to be disclosed, and continue to work as a source on the PFL, if he partook in PLF operations. Essentially, his actions were therefore in line with MfS expectations. Both also stressed that they believed in his loyalty but even if Hepp disclosed his Stasi contacts, there would be no evidence of his trip to and stay in the GDR..$^{93}$ In their assessment at least, there was no real need to worry. Whether this is a reflection of their real opinion or some sort of Zweckoptimismus - often practiced by GDR officials - is unclear. Böttcher and Kießling might have truly believed that; but downplaying the risks might also have been a tactical move to deflect criticism of their handling of the situation and for allowing such a crisis to occur.

Their superiors agreed with their evaluation of the situation. Consequently, rather than finally closing the Hepp file, the Stasi developed strategies for possible future modes of collaboration once Hepp was released from prison. Böttcher and Kießling also elaborated plans to send messages to his prison cell to encourage him to stay put and not to give in and reveal information. Moreover, the Stasi also put Hepp's family and friends under closer surveillance so as to catch any indication of him changing sides as soon as possible. ${ }^{94}$ It appears that at least one of the Stasi's sources on Hepp's imprisonment in France was Klaus Croissant who was a former RAF lawyer and sympathiser, and frequented people associated with the Action Directe and Hepp's French lawyers. It was later revealed that Croissant was the Stasi informant 'Taler' ${ }^{95}$ This is only a glimpse at the extensive network of informants and spies the Stasi maintained in the West - beyond the Federal Republic. ${ }^{96}$

\footnotetext{
${ }^{91}$ AOPK 7896/91, Bd. 1, doc.142.

92 AOPK 7896/91, Bd. 1, doc.130, 135, 152-3, 155-6, 164.

${ }^{93}$ AOPK 7896/91, Bd. 1, doc.137-8.

${ }^{94}$ AOPK 7896/91, Bd. 1, doc. 155-6, 164.

95 'Anwälte: Aufgelöst Und Hilflos', Der Spiegel, 21 September 1992, http://www.spiegel.de/spiegel/print/d13682116.html; Winterberg, Der Rebell, 311; 'Der RAF-Anwalt Im Untergrund', Der Tagesspiegel, 29 March 2002, http://www.tagesspiegel.de/politik/der-raf-anwalt-im-untergrund/301044.html.

${ }^{96}$ For more information on the Stasi's network of spies see footnote 5.
} 
Böttcher's and Kießling's estimation that Hepp would not reveal information on the Stasi connection was not based on any facts other than their own assessment of his character and his loyalty. ${ }^{97}$ Their solution to the problem - to basically just monitor the situation and see what happens - once again evoked criticism from other MfS departments, which cynically noted that 'if nothing more were to be done, as suggested by you, then we could all just lean back, right.' However, Böttcher and Kießling were allowed to continue with their approach. ${ }^{98}$

Meanwhile, Franco-German cooperation interestingly did not extent to the Hepp case, as the French authorities refused to allow BKA officers to interrogate Hepp in Paris and to extradite him to the FRG. Paris wanted to try him for his involvement with the PLF in France first before sending him to West Germany. ${ }^{99}$ Encouraged by this decision and the alleged display of sympathy by the French authorities to his cause - or at least lack of willingness to cooperate with the West Germans - Hepp even went so far as to demand political asylum in France. The French would not play along, however, and his petition was rejected. On 21 May 1986, the Paris trials against Hepp started and he was sentenced to two years' imprisonment. In another attempt to prevent his extradition to West Germany, he wanted to marry an Arab woman so as to gain the nationality of an Arab state, but that did not work out either. ${ }^{100}$ What is remarkable in this context, however, is the extent to which the Stasi was aware of all of this and how the surveillance apparatus put in place worked. They even had copies of the letters Hepp sent from his prison cell and which were intercepted on their way to his family and friends.

When the end of his French prison sentence drew closer, the MfS made plans for how to proceed with Hepp should he be released. It was decided to re-establish contact with him 'in due course' to continue the pre-arrest collaboration. Apparently Hepp still had value for the GDR. However, the French authorities agreed to the West German extradition request and on 28 January 1987 he was sent to the FRG. ${ }^{101}$ There he stood trial for his involvement in the bombings of US cars, bank robberies, and membership in a terrorist organisation and on 27 October 1987 Hepp was sentenced to ten-anda-half years of imprisonment. During the trials, he was willing to collaborate with the authorities and

\footnotetext{
97 AOPK 7896/91, Bd. 9, doc. 146.

${ }^{98}$ AOPK 7896/91, Bd. 9, doc. 205.

${ }^{99}$ AOPK 7896/91, Bd. 1, doc.144. Interestingly enough, in the 1970s, French authorities were also very reluctant to extradite people accused of supporting left-wing terrorism to the FRG, see e.g. Blumenau, The United Nations and Terrorism, 39, footnote 165 on p. 223. The lack of extradition agreements covering terrorism had been one of the primary reasons for international agreements concerning this matter to be negotiated within the European Communities and Council of Europe, see Bernhard Blumenau, 'Taming the Beast: West Germany, the Political Offence Exception, and the Council of Europe Convention on the Suppression of Terrorism', Terrorism and Political Violence 27, no. 2 (2015): 310-30; Bernhard Blumenau, 'The European Communities' Pyrrhic Victory: European Integration, Terrorism, and the Dublin Agreement of 1979', Studies in Conflict \& Terrorism 37, no. 5 (2014): 405-21.

100 AOPK 7896/91, Bd. 1, doc. 213-4.

101 AOPK 7896/91, Bd. 9, doc. 63.
} 
testified against neo-Nazis. He also admitted some guilt, which led to a shorter sentence. ${ }^{102}$ Yet, as far as available documentation today suggests, he kept his word and his deal with Böttcher and Kießling and never revealed his relationship with the MfS. The Stasi would not forget about him either. Two months before the fall of the Wall in 1989, Kießling was still making plans for how to use Hepp in the future. ${ }^{103}$ Yet, the peaceful revolution in East Germany in the autumn of 1989 and the corresponding demise of the GDR and MfS prevented any further plans from being implemented. It was only after 1990, once the GDR had gone, that Hepp began to talk about his contacts to and stay in the GDR. ${ }^{104} \mathrm{He}$ was released from prison in 1993 and successfully reintegrated into society; and broke with and condemned his terrorist past. ${ }^{105}$

\section{Conclusion}

This account of the relationship between Odfried Hepp and the Stasi is more than just a biographical sketch. It offers insights into how the Stasi worked internally, on what bases decisions were made, how little control they had over some of their informants, the considerable risk they exposed themselves to in its secret war against West Germany. The ideological shade of its ally in this struggle was of little consequence: the Stasi was just as willing to work with left-wing - allegedly ideologically sympathetic - groups as with the ideological enemy, right-wing neo-Nazis. While the East German regime took every opportunity to openly and loudly discredit the FRG and its political leadership because of its purported fascist legacy, evidently silent cooperation with convinced neo-Nazis posed no serious scruples. Odfried Hepp is but one example of this policy. ${ }^{106}$ Despite a limited rapprochement with the Stasi on certain ideological aspects (friendship with the USSR for one, anti-Americanism for another), Hepp never broke with his neo-Nazi thoughts nor accepted the leading role of the Communist Party. In their collaboration with Hepp, the Stasi produced a perfect case study of realpolitik and how pragmatic considerations trumped any ideological hesitations.

The case examined here allows for other observations as well. For one, it illustrates the wideranging relationship between the Stasi and terrorism. While the GDR openly condemned terrorism, cooperating with members of terrorist organisations was a constant in MfS policies. The goal was to stir up the situation in West Germany and create some trouble for the authorities; not so much though that the FRG government as such was in jeopardy. Terrorism was supposed to be a nuisance for West

\footnotetext{
102 AOPK 7896/91, Bd. 14, doc. 224.

${ }^{103}$ AOPK 7896/91, Bd. 14, doc. 115-9.

104 Heike Hupertz, 'Fernsehen: Ein Links-rechts-Terrorist packt aus: „Der Rebell“ bei Arte', Frankfurter Allgemeine Zeitung, 7 November 2005, http://www.faz.net/aktuell/feuilleton/kino/fernsehen-ein-links-rechtsterrorist-packt-aus-der-rebell-bei-arte-1279122.html; Winterberg, Der Rebell, 333-34, 344-45.

${ }^{105}$ See Winterberg, Der Rebell, 346-62, 371-74. For Böttcher's life after 1989 see Winterberg, 359.

106 That the Stasi cooperated with other informants in right-wing circles can be seen for instance in AOPK 7896/91, Bd. 1, doc. 21. See also Winterberg, Der Rebell, 229, 239.
} 
German officials, not more. ${ }^{107}$ This policy also applied to Hepp. Rather than using him as a proxy in the Cold War against Bonn and encouraging him to commit new attacks, the MfS instructed him to keep a low profile and not to resort to terrorism again. He was supposed to be a source of information, not an instigator of new terror in the West. This shows that the Stasi's links with terrorists existed essentially for intelligence purposes; they were not an instrument in the Cold War, contrary to Sterling's Terror Network hypothesis. There was also the risk that comprehensive counterterrorism efforts would put at risk covert Stasi agents in West Germany and therefore, the Stasi had no interest in excessive domestic terrorism in the FRG. ${ }^{108}$ At the same time, links with terrorists were kept for very selfish reasons: the Stasi wanted to prevent terrorism from spilling into East Germany. Following this logic, it made sense to also keep a close eye on right-wing groups. In the case of Hepp, this is how cooperation started as well. Hepp offered information on possible neo-Nazi attacks on the GDR, and this was what got the Stasi's attention. Later on he would also prove useful in supplying information on the PLF. In the early stages of their mutual relationship, the balance was somewhat even. Hepp did not need much from the Stasi and hence their leverage on him was low. It appears that Hepp, contrary to most other Western terrorists in contact with the Stasi, looked for the rapprochement because of a genuine perception of shared goals, and not out of necessity. It was only when he was about to be arrested in West Berlin that the tables turned. Now he needed Stasi support to escape imprisonment. Yet the Stasi did not deliver him to his fate but agreed to shelter him in the GDR, which came at considerable potential costs for the international prestige of the GDR. Being fully aware of the liability that was Odfried Hepp living the East Germany, at a time when roughly a dozen former left-wing terrorists were also hiding in the GDR, the MfS approved of plans to relocate him to the Middle East. Certainly, Hepp could have worked as an informant on Palestinian activities but only in a distant future. No immediate gains were to be reaped and the insights he would produce on the PLF were not only unforeseen by the Stasi when his relocation to Syria was decided; they were in blatant contradiction to MfS instructions. Once again, the Stasi took risks when relocating him; it would have been easier for him to be discovered by other intelligence agencies once he left the GDR. It appears that sending him away served two purposes: remove him from GDR territory at a time West Germans might be more closely looking for terrorists-in-hiding there, and build him up as a potential future source in a region of continuing geopolitical importance.

As the Stasi had only very limited means of control over Hepp once he was out of the GDR, another interesting observation is the importance of the personal relationship between Hepp and his

\footnotetext{
107 See for instance Michael Ploetz, 'Mit RAF, Roten Brigaden Und Action Directe. Terrorismus Und Rechtsextremismus in Der Strategie von SED Und KPdSU', Zeitschrift Des Forschungsverbundes SED-Staat, no. 22 (2007): 125, 131-32.

108 For this argument see also Wörle, 'Erdung Durch Netzwerkstruktur? Revolutionäre Zellen in Deutschland', 266.
} 
case officers, Kießling and Böttcher. Building a strong personal relationship, as well as a sense of loyalty for the GDR and its ideology was the only way to ensure Hepp's discretion regarding his GDR past, and his continuing cooperation. Judging from the documents, the Stasi men and Hepp developed close, almost friendly, ties and this explains the level of trust that both Stasi agents extended to Hepp's word and loyalty once he was in the Middle East, and later in a French prison. In the absence of any other securities, they served as the basis for the Stasi's continuing relationship with and support of Hepp, even at a time when he was getting actively involved in PFL operations. For an intelligence agency such as the Stasi, personal links always mattered but in this case, they were a liability and could have also worked to the potential disadvantage of the agency. Had Hepp not been as loyal as Kießling and Böttcher thought him to be, he could have done some serious damage to the GDR by revealing his contacts at the Stasi to the BND as well as the location of his hideouts in the GDR and information on Stasi operations. Had his connection been uncovered, the global prestige, something the GDR was so eager to defend, could have suffered. Even though no hard evidence could have likely been produced for his support from the GDR, the claim alone, coming from a West German neo-Nazi - someone who would normally not willingly want to be associated with the Socialist GDR - would have raised questions, and led to unpleasant headlines for East Berlin. This would have damaged the GDR's claim, and by extension that of the USSR, of not supporting terrorists. ${ }^{109}$ It was a gamble with fire which the MfS was nevertheless willing to play to keep this informant.

As an insightful side note, the Hepp case also points to the lack of trust that existed among Eastern intelligence agencies. Under no circumstances was Hepp to reveal to other Socialist services that he was cooperating with the Stasi and likewise, the MfS kept the purpose of its visits with and the identify of its informant hidden from Hungarian agencies when they planned the meetings in the Hotel Royal. Socialist solidarity and trust had their limits.

Lastly, the wealth of intelligence on Hepp from West German and French sources shows just how extensive the Stasi network of informants in the West really was. The MfS tapped into the BKA information system, had top-secret documents from West German ministries and courts, and had enough contacts in France to keep a close eye on Hepp when he was in prison. It was certainly because of the Stasi's deeply non-ideological pragmatism and its willingness to enter into unholy alliances whenever there was an opportunity that this extensive network came into being.

In sum, this article provides a profile of someone who gradually radicalised and moved towards terrorism - a theme that this article could only touch upon. Yet it also shows the risks involved in states associating with terrorists; and that the MfS was far from being the all-mighty and all-knowing

\footnotetext{
${ }^{109}$ For that claim see for instance Blumenau, 'The Other Battleground of the Cold War', 70-71; Blumenau, The United Nations and Terrorism, 128.
} 
institution it was (self-)portrayed as. The Stasi could have easily been caught in the very extensive net of agents it was trying to cast into the West. 